\title{
Support Provision in Greek Higher Education: Examining Students' Accounts
}

\author{
Olga Tzafea, Panagiota Gkofa \& Eleni Sianou-Kyrgiou \\ University of Ioannina, School of Philosophy, GREECE \\ Antigone Sarakinioti \\ Aristotle University of Thessaloniki, GREECE \\ School of Philosophy and Education
}

Received: 24 July 2020 - Accepted: 15 September 2020 - Published Online: 3 October 2020

\begin{abstract}
In the last decades, despite the implementation of policies aiming at widening the participation in higher education in many countries, inequalities persist. Drawing on survey data collected in the context of our research project exploring aspects of Diversity, Inequalities and Inclusion in Greek higher education, this article presents undergraduate students' accounts on the support measures provided in higher education. Our findings indicate that undergraduate students express rather reserved views on the effectiveness of the support measures provided. Some characteristics are of importance in these students' accounts as some groups consider institutions as less supportive such as females and students who have not completed their studies on time. A strong effect of the institution of study on students' views regarding support provision is also shown revealing the key role of institutions on the students' trajectories.
\end{abstract}

Keywords: higher education, social inequalities, student support provision.

\section{Introduction}

Increasing and widening participation as well as improving the quality and relevance of higher education have been prioritized by the European Commission the last decade (EC, 2019). Relevant policies have focused on promoting inclusion and equity (Reay, 2017; Shavit, Arum \& Gamoran, 2007), but they also stress access to opportunities once at university (Crozier, Reay \& Clayton, 2019; Archer \& Hutchings, 2000) and student success (Troxel, 2010; Thomas, 2002). Research studies indicate that the participation of socially diversified groups in higher education triggers new forms of inequalities creating new challenges for higher education policy agendas (Burke, Crozier \& Misiaszek, 2016; Archer, 2007). Despite the attempts to widen participation in higher education and democratize it, inequalities persist (Crozier et al., 2019; Reay, 2017).

Relevant literature shows that students, especially those coming from non-privileged backgrounds, confront difficulties throughout their academic life in relation to learning, responding to curriculum, relationships with teaching staff (Crozier et al., 2008; Archer, Hutchings \& Ross, 2003; Purcell, Elias, Atfield, Behle, Ellison, Hughes \& Tzanakou, 2009; Croll \& Attwood, 2013; Reay, Crozier \& Clayton et al., 2009) as well as academic and social inclusion

(C) Authors. Terms and conditions of Creative Commons Attribution 4.0 International (CC BY 4.0) apply. Correspondence: Olga Tzafea, Annis Komninis 1, Ioannina, 45221, GREECE. E-mail: olgatzaf@gmail.com, olgatzaf@uoi.gr. 
(Sianou-Kyrgiou, 2010; Troxel, 2010; Trowler, 2010). Student support is critical in helping students progress and complete their studies (Barberis \& Loncle, 2015). Financial support is significant, especially for students from poorer background, but not per se a solution to underrepresentation (Long, 2008). The importance of Information, Advice and Guidance (IAG) is revealed by studies showing that the well-informed students have better chances to progress and also have better long-term employment outcomes (Thomas \& Jones, 2007). Key to retention and success are supportive peer relations (Wilcox, Winn \& Fyvie-Gauld, 2005; Foster, Lawther, Keenan, Bates, Colley \& Lefever, 2011); family support (Foster et al., 2011); meaningful interaction between staff and students (Thomas, 2012); knowledge, confidence and identity as successful HE learners (Crozier \& Reay, 2008). The European Commission promotes the "social dimension of higher education" encouraging European countries to implement support measures in relation to access to higher education, progression and completion rates (EC, 2018). The same applies for the Greek context which is described below in more detail.

- In Greece, undergraduate students express rather reserved views on the effectiveness of the support measures provided in higher education.

- Some groups of students consider institutions as less supportive such as females and students who have not completed their studies on time.

- Students' accounts on support provision in higher education get differentiated on the basis of the institution of attendance; this reveals the key role of institutions on the students' trajectories.

HE in Greece is exclusively provided by public institutions (Saiti \& Prokopiadou, 2008). ${ }^{1}$ Students enter HE on the basis of the score accomplished at the nationwide (Panhellenic) exams in the end of upper secondary education on a numerus clausus basis; when the demand outnumbers the available places, the students with the higher grades are admitted (SianouKyrgiou, 2010). Therefore, despite the absence of official ranking tables for Greek universities, the Greek HE system is considered to be selective on the basis of the demand that leads to high admission qualifications at least for specific universities/departments.

In the Greek HE system, widening participation initiatives have been promoted (EC, 2019). Positive discrimination measures facilitate university access for groups of students through distinct routes, such as: (a) participation in different exams (e.g. Greek expatriates), (b) being offered lower limit grades/special places, such as students of the Muslim minority of Thrace (Askouni, 2006) and disabled students (Law 3794/2009), or (c) having the Panhellenic Exams grade requirements waived (e.g. students who have achieved distinction in academic or athletic competitions). Moreover, the current lack of a minimum limit performance (10 out of 20 points) for university entrance (Stamelos, 2020) facilitates students to access HE (Sianou-Kyrgiou, 2010). However, research shows that students coming from disadvantaged groups often face problems that have a strong impact on their performance, completion of their studies and their academic trajectories (Sianou-Kyrgiou, 2010).

Taking the above into account, it is expected that the diversity of student population has increased in Greek HE but the same is expected for the obstacles students meet. Indicatively, late or non-completion is a problem in Greek HE (EC, 2019; Stamelos, 2020). Existing data shows that from 2000 until 2015, the increase of university students who have exceeded the expected period of studies in Greece reached 108.6\% (Ibid.). In response, support measures are provided for HE students.

${ }^{1}$ Currently 25 HE institutions operate as self-governed entities which are financed and supervised by the Greek Ministry of Education (Law 4009/2011) (Sianou-Kyrgiou \& Tsiplakides, 2011). 
The first type of support provided after university entrance is financial support. Despite the no-fee policy for undergraduate courses (EC, 2018), study costs should be considered especially under the financial crisis of the last decade (Zmas, 2015). Greece provides needs-based grants through which $1 \%$ of the undergraduate students benefits (EC, 2018). ${ }^{2}$ Tax benefits for students' parents and rental allowances for undergraduates studying away from the family home are also provided (EC, 2018). Second, the Law 4009/2011 foresees the establishment of student support services at Greek HE institutions regarding academic guidance, psychological support, career, employability and counseling. Despite the importance of support provision in HE, relevant studies are limited (Stamelos, 2020). As regards monitoring practices, Greece performs poorly, a fact which prevents the effective implementation of the retention policies and the Greek research in HE (Stamelos, 2020). Widening participation for under-represented groups is addressed but work needs to be done in terms of monitoring of socio-economic background of students, recognition of informal or non-formal learning on entry to higher education, completion rates and performance based funding mechanisms with a social dimension focus (EC, 2019). This article explores this lacuna for the Greek context aiming at examining how undergraduate students account on the support measures provided in Greek higher education.

\section{Method}

This article draws on data collected for our research project entitled "Educational trajectories in Greek higher education: Diversity, Inequalities and Inclusion" (University of Ioannina, Greece, 2018-2019) which examined aspects of inequalities and student support in Greek higher education. 3 The study was conducted in three Greek higher education institutions which were selected as having different institutional characteristics, such as historical origin, location development of infrastructure, degree of selectivity because, for the research purposes of the project, such institutional differences are examined as important for the Greek case ${ }^{4}$. Both institutions and individuals are anonymised. In particular, this article presents quantitative data from the questionnaire undergraduate students completed on their views on student support provided during their studies in Greek HE. The research question underpinning this study is as follows: "How do students account on support measures provided by Greek HE institutions?".

The questionnaire has been originally developed in course of the research project to measure the perceptions, the knowledge and the values of the students on diversity, inequalities, exclusions and student support. The first part of the questionnaire consists of items about demographic characteristics and personal information (see Table 1 below) while the second part includes items which refer to (1) access to higher education: choices and expectations of studies, (2) academic and social integration to university life (satisfaction and difficulties encountered during studies), (3) inequalities and diversity at university, (4) support services and (5) future plans. Most questions have been designed on a Likert scale from 1 (not at all/extremely unimportant to me) to 5 (completely/extremely important to me). The questionnaire has been

2 Indicatively, the Greek State Scholarships Foundation prioritizes the following characteristics when providing grants for socially vulnerable students (IKY, 2019): low annual family income (up to 7,500 euros), disabilities/health problems, being a member of single or large families, status of orphan - expatriate refugee - Roma - migrant - member of the Muslim minority of Thrace - seropositive - ex-addict - exprisoner.

3 Our research project's methodology was based on a mixed methods approach which included (a) questionnaires examining students' views and experiences on inequalities and student support services in higher education; (b) interviews with students who confronted difficulties during their academic trajectories; (c) interviews with academic staff exploring academics' knowledge and experiences on the strategies that their institutions develop to address inequalities and provide support.

4 Relevant findings are under publication elsewhere. 
piloted on an earlier cohort a semester before the data collection and improvements have been made. This publication presents data from the fourth part of the questionnaire on student support provision. In particular, three aspects of support measures have been investigated: (A) Support provided by teaching staff and student fellows (Amean); (B) Support provided by established institutional structures and practices (Bmean), and (C) Support provided for managing diversity and discrimination (Cmean).

The research was conducted from April to June 2019. The sampling was convenient. The researchers (who are the authors of this publication) approached teaching staff at each institution and, after their permission, visited the classrooms on times suggested, presented the research and asked undergraduate students sitting at least the $3^{\text {rd }}$ academic year of their studies to complete the questionnaire during their break. Students in their last academic years were mainly asked to participate, anonymously and on a volunteer basis, as these students would have had a fuller account on academic life, experiences and support services. The respondents come from all faculties and schools of each institution and completed the hardcopy questionnaires during the course break or in the end of the course. Finally, 1,260 questionnaires were fully completed and used for the statistical analysis.

Regarding the ensuing statistical analysis we note the use of descriptive statistics techniques, independent samples t-test and analysis of variance and corresponding post-hoc procedures through the SPSS statistical software. More specifically, data analysis started with the descriptive statistics of the questionnaire items. For the set of questions under examination, we computed an average score; before computing these scores, we have checked the correlation values and Cronbach's reliability coefficients. Average scores for each of the items of the questionnaire have been calculated for the whole sample and have also been split on the basis of differences in demographic characteristics. As each item of the questionnaire was treated as a separate issue, they were not combined to form a composite score. This means that scores ranged from 1 to 5 for each item (not applicable responses were treated as missing data as the item was not relevant to that respondent) and were therefore measured at an ordinal level. Accordingly, all statistical tests used were non-parametric. Our analysis continued with assessing the effect of questions; in particular, the statistical analysis contained the assessment of the independence of the respondents' characteristics on Amean, Bmean and Cmean. We assessed the effect of questions included in Table 4 on the three average scores, using independent samples t-test and analysis of variance (and corresponding post-hoc procedures).

\section{Results}

\subsection{Students' profiles}

A descriptive statistical analysis was conducted to obtain a general understanding of the students' profiles. Most students were females (68.9\%) and $79.2 \%$ of the respondents were $3^{\text {rd }}$ or $4^{\text {th }}$ year students. This rate can be explained by the higher number of women studying in Greek $\mathrm{HE}$, and by women's general tendency to take part in studies more willingly compared to their male counterparts (Buchmann \& Di Prete, 2006). Annual family income ranges between 10,000 30,000 euros for a significant percentage of respondents (33.8\%: 10,001-20,000 euros, 23.9\%: 20,001-30,000 euros). Most students' fathers were occupied as employees or self-employed in specialised professional posts of mid-level status of the public or private sector (52.9\%) while students' mothers were employed mostly as semi-skilled/unskilled workers or farmers (37.4\%). As regards parents' education, $46.2 \%$ of the students' fathers had completed secondary schools and $35.7 \%$ had a bachelor degree, while $47.1 \%$ and $38 \%$ of students' mothers had secondary education qualifications and bachelor degrees respectively. 40.5\% of the respondents were first generation students. The differences among the institutions in terms of size are reflected in the 
representation of the respondents in the sample as $52.4 \%$ of the respondents attended UniA, $32 \%$ Uni B and 15.6\% UniC. Table 1 presents the respondents' background information in detail.

Table 1. Demographic and socioeconomic background of the respondents

\begin{tabular}{|c|c|c|c|c|c|}
\hline 1. Gender & Male & Female & & & \\
\hline & $31.1 \%$ & $68.9 \%$ & & & \\
\hline \multirow[t]{2}{*}{ 2. Year of Study } & $<3$ rd & 3rd & 4th & $>$ 4th & \\
\hline & 13.1 & $23,30 \%$ & $42.8 \%$ & $20.8 \%$ & \\
\hline \multirow[t]{2}{*}{ 3. First in immediate family to attend university } & Yes & No & & & \\
\hline & $40.5 \%$ & $59.5 \%$ & & & \\
\hline \multirow[t]{2}{*}{ 4. Institution of study } & UniA & UniB & UniC & & \\
\hline & $52.4 \%$ & $32 \%$ & $15.6 \%$ & & \\
\hline \multirow[t]{2}{*}{ 5. Annual family income (€) } & $\leq 5000$ & $\begin{array}{l}5001- \\
10000\end{array}$ & 10001-20000 & 20001-30000 & $>\mathbf{3 0 0 0 0}$ \\
\hline & $9.6 \%$ & $18.9 \%$ & $33.8 \%$ & $23.9 \%$ & $13.9 \%$ \\
\hline \multirow[t]{2}{*}{ 6. Cost of studies per month $(€)$} & $\leq \mathbf{3 0 0}$ & 301-500 & 501-700 & $>700$ & \\
\hline & $51.3 \%$ & $28.8 \%$ & $15.8 \%$ & $4.1 \%$ & \\
\hline 7. Parents' occupation * & $\mathbf{1}$ & 2 & 3 & 4 & 5 \\
\hline $\begin{array}{l}\text { 7.1 Father } \\
\text { 7.2 Mother }\end{array}$ & $\begin{array}{l}9.4 \% \\
14.0 \%\end{array}$ & $\begin{array}{l}52.9 \% \\
13.1 \%\end{array}$ & $\begin{array}{l}29.1 \% \\
27.8 \%\end{array}$ & $\begin{array}{l}7.1 \% \\
37.4 \%\end{array}$ & $\begin{array}{l}1.5 \% \\
7.7 \%\end{array}$ \\
\hline 8. Parents' education & Primary & Secondary & Bachelor & Master/ PhD & \\
\hline $\begin{array}{l}\text { 8.1. Father } \\
\text { 8.2. Mother }\end{array}$ & $\begin{array}{l}8.9 \% \\
6.8 \%\end{array}$ & $\begin{array}{l}46.2 \% \\
47.1 \%\end{array}$ & $\begin{array}{l}35.7 \% \\
38.0 \%\end{array}$ & $\begin{array}{l}9.1 \% \\
8.1 \%\end{array}$ & \\
\hline
\end{tabular}

* ${ }_{1}$. High-level executives or employers in the public/ private sector, self-employed in business orin high status professions (lowers, doctors).

2. Employees or self-employed in specialised professional posts of mid- level status in public or private sector (civil servants with university degrees, teachers)

3. Employees in manual/non manual working posts of lower status in public and private sector, self-employed craftsmen/ practitioners, owners of small businesses.

4. Semi-skilled, unskilled workers/farmers

5. Never working, unemployed persons

\subsection{Students' accounts on support provision}

The data analysis section draws on data from three items of the questionnaire regarding students' accounts and experiences on the support they received during their studies counted on a five-level Likert scale, starting from "not at all" (1) to "completely (5).

First, students were asked about the support they received from the teaching staff and student fellows (variable Amean). In particular, the first item included the following sub-items: (1) The teaching staff encouraged me to improve during the courses; (2) The teaching staff is very friendly and willing to help with any problems related to my studies; (3) There is good cooperation and close communication with the teaching staff; (4) The teaching staff did everything they could to make the lessons more pleasant; (5) I hang out with people I met at university; (6) I think I do not have the same opportunities as my colleagues do; (7) My colleagues treat me fairly and equally during the courses.

Second, students were asked about their satisfaction about the support measures they met by their institution in order to have a better social and academic engagement (variable Bmean). The second item on support included the following sub-items: (1) Support of new entrants from the institution (informative meetings, events, material, etc.); (2) Support for active participation in student life and opportunities to meet other students; (3) Support for getting 
familiar with the new environment of my university (buildings, secretariats, libraries, staff's offices, services); (4) Update on the course selection process; (5) Update on course requirements; (6) Update on prerequisite courses and the suggested selection/sequence per semester; (7) Offering courses and educational activities according to the curriculum; (8) Use of knowledge and skills you have developed as students; (9) Opportunities to participate in clubs, cultural activities and sports.

Third, students were asked about their perspectives regarding the support measures institutions take in order to combat specific types of inequalities, in particular: (1) Combat gender inequality; (2) Support students from other nationalities; (3) Support students of an immigrant background; (4) Support students from low socioeconomic background; (5) Support students with financial difficulties; (6) Support students with disabilities; (7) Provide equal opportunities for the academic success of all; (8) Implement effective measures for managing diversity.

For each set of sub-questions of A, B and C variables, we computed a mean value. Before computing these scores, we checked the correlation values and Cronbach's reliability coefficients for each set of items. Table 2 presents some descriptive data of the variables as well as their reliability index. It is observed that all variables are reliable scales (Cronbach's Alpha> 0.6). According to Table 2, students, in their majority, express rather reserved views on the readiness and effectiveness of institutions to implement student support provision. The support students received from the teaching staff and colleagues has a larger mean value, satisfaction about the support measures students met by their institution in order to have a better social and academic engagement follows and last come the support measures institutions take in order to combat inequalities.

Table 2. Descriptive statistics and Cronbach's Alpha scale

\begin{tabular}{|l|c|c|c|}
\hline Variable & Mean value & $\begin{array}{c}\text { Standard } \\
\text { Deviation }\end{array}$ & Cronbach'sAlpha \\
\hline Amean & 3.00 & 0.68 & 0.705 \\
\hline Bmean & 2.71 & 0.80 & 0.888 \\
\hline Cmean & 2.56 & 0.93 & 0.930 \\
\hline
\end{tabular}

Table 3 presents the correlations among variables A, B and C. All variables have a strong positive correlation. Thus, the less support students feel they received from teaching staff and colleagues, the less supportive they find the measures implemented for social and academic engagement as well as the measures institutions take in order to combat inequalities. The strongest correlation is observed between Amean and Bmean. In other words, the less students claim that they get support by teaching staff and colleagues, the less they claim that they get support by the institution.

Table 3. Correlations among variables A, B, C

\begin{tabular}{|c|c|c|c|}
\hline & $\mathrm{A}$ & $\mathrm{B}$ & $\mathrm{C}$ \\
\hline $\mathrm{A}$ & 1 & & \\
\hline $\mathrm{B}$ & $0.532^{* *}$ & 1 & \\
\hline $\mathrm{C}$ & $0.375^{* *}$ & $0.433^{* *}$ & 1 \\
\hline
\end{tabular}

Our interest in the research project focuses on groups of students which might be in greater need of support. Therefore, the statistical analysis continues with assessing the independence of the respondents' characteristics (Table 1) on institutional support categories (A, $\mathrm{B}$, and $\mathrm{C}$ ) in order to explore possible characteristics which matter the most. The main statistical 
tools used were independent samples t-test and analysis of variance (and corresponding post-hoc procedures. The results are presented in detail in Table 4.

Table 4. The equality of means among categories (using ANOVA and multiple comparisons), for the mean scores of the items A, Band

\begin{tabular}{|c|c|c|c|c|c|c|c|c|c|c|c|c|c|}
\hline \multirow{3}{*}{ Demographics } & & \multicolumn{12}{|c|}{ Variables } \\
\hline & & \multicolumn{4}{|c|}{ Amean } & \multicolumn{4}{|c|}{ Bmean } & \multicolumn{4}{|c|}{ Cmean } \\
\hline & & $\mathbf{N}$ & Mean & S.D & $\mathbf{p}$ & $\mathbf{N}$ & Mean & SD & $\mathbf{p}$ & $\mathbf{N}$ & Mean & SD & $\mathbf{p}$ \\
\hline Gender & $\begin{array}{l}\text { Male } \\
\text { Female }\end{array}$ & $\begin{array}{l}407 \\
907\end{array}$ & $\begin{array}{l}3.08 \\
2.97\end{array}$ & $\begin{array}{l}0.69 \\
0.67\end{array}$ & $0.008^{*}$ & $\begin{array}{l}401 \\
895\end{array}$ & $\begin{array}{l}2.77 \\
2.69\end{array}$ & $\begin{array}{l}0.80 \\
0.80\end{array}$ & 0.11 & $\begin{array}{l}340 \\
813\end{array}$ & $\begin{array}{l}2.67 \\
2.53\end{array}$ & $\begin{array}{l}0.94 \\
0.93\end{array}$ & $0.037^{*}$ \\
\hline $\begin{array}{l}\text { Year of } \\
\text { study }\end{array}$ & $\begin{array}{l}4^{\text {th }} \\
>4^{\text {th }}\end{array}$ & $\begin{array}{l}1051 \\
262\end{array}$ & $\begin{array}{l}3.22 \\
2.81\end{array}$ & $\begin{array}{l}0.68 \\
0.65\end{array}$ & $<0.01^{*}$ & $\begin{array}{l}1050 \\
261\end{array}$ & $\begin{array}{l}3.76 \\
3.38\end{array}$ & $\begin{array}{l}0.61 \\
0.68\end{array}$ & $<0.01$ & $\begin{array}{l}957 \\
233\end{array}$ & $\begin{array}{l}3.07 \\
2.67\end{array}$ & $\begin{array}{l}0.61 \\
0.96\end{array}$ & $<0.01$ \\
\hline $\begin{array}{l}\text { First to } \\
\text { attend } \\
\text { university }\end{array}$ & $\begin{array}{l}\text { Yes } \\
\text { No }\end{array}$ & $\begin{array}{l}539 \\
770\end{array}$ & $\begin{array}{l}3.11 \\
2.93\end{array}$ & $\begin{array}{l}0.68 \\
0.67\end{array}$ & $<0.01^{*}$ & $\begin{array}{l}532 \\
761\end{array}$ & $\begin{array}{l}2.74 \\
2.67\end{array}$ & $\begin{array}{l}0.82 \\
0.78\end{array}$ & 0.116 & $\begin{array}{l}476 \\
675\end{array}$ & $\begin{array}{l}2.58 \\
2.55\end{array}$ & $\begin{array}{l}0.82 \\
0.91\end{array}$ & $<0.01^{*}$ \\
\hline $\begin{array}{l}\text { Institution } \\
\text { of study }\end{array}$ & $\begin{array}{l}\text { UniA } \\
\text { UniB } \\
\text { UniC }\end{array}$ & $\begin{array}{l}672 \\
411 \\
218\end{array}$ & $\begin{array}{l}2.89 \\
3.01 \\
3.35\end{array}$ & $\begin{array}{l}0.614 \\
0.71 \\
.69\end{array}$ & $<0.01^{*}$ & $\begin{array}{l}663 \\
407 \\
213\end{array}$ & $\begin{array}{l}2.54 \\
2.77 \\
3.12\end{array}$ & $\begin{array}{l}0.74 \\
0.79 \\
0.83\end{array}$ & $<0.01^{*}$ & $\begin{array}{l}581 \\
360 \\
197\end{array}$ & $\begin{array}{l}2.51 \\
2.47 \\
2.89\end{array}$ & $\begin{array}{l}0.91 \\
0.91 \\
0.99\end{array}$ & $<0.01^{*}$ \\
\hline $\begin{array}{l}\text { Anual } \\
\text { family } \\
\text { income (€) }\end{array}$ & $\begin{array}{l}<5 \mathrm{~K} \\
5001-10 K \\
10001-20 K \\
20001-30 K \\
>30001\end{array}$ & $\begin{array}{l}119 \\
239 \\
426 \\
292 \\
173\end{array}$ & $\begin{array}{l}2.73 \\
2.70 \\
2.69 \\
2.69 \\
2.75\end{array}$ & $\begin{array}{l}0.85 \\
0.80 \\
0.78 \\
0.75 \\
0.87\end{array}$ & 0.897 & $\begin{array}{l}120 \\
242 \\
429 \\
296 \\
175\end{array}$ & $\begin{array}{l}3.03 \\
3.06 \\
2.98 \\
2.98 \\
2.98\end{array}$ & $\begin{array}{l}0.70 \\
0.66 \\
0.68 \\
0.65 \\
0.73\end{array}$ & 0.647 & $\begin{array}{l}46 \\
101 \\
214 \\
380 \\
264\end{array}$ & $\begin{array}{l}2.38 \\
2.52 \\
2.60 \\
2.56 \\
2.49\end{array}$ & $\begin{array}{l}1.00 \\
0.89 \\
1.01 \\
0.91 \\
0.82\end{array}$ & 0.704 \\
\hline $\begin{array}{l}\text { Cost of } \\
\text { studies } \\
\text { per month } \\
\text { (E) }\end{array}$ & $\begin{array}{l}<300 \\
301-500 \\
501-700 \\
>701\end{array}$ & $\begin{array}{l}647 \\
364 \\
203 \\
51\end{array}$ & $\begin{array}{l}2.66 \\
2.71 \\
2.77 \\
2.90\end{array}$ & $\begin{array}{l}0.79 \\
0.76 \\
0.80 \\
1.01\end{array}$ & 0.121 & $\begin{array}{l}652 \\
372 \\
204 \\
51\end{array}$ & $\begin{array}{l}2.99 \\
3.03 \\
2.96 \\
3.08\end{array}$ & $\begin{array}{l}0.66 \\
0.68 \\
0.66 \\
0.86\end{array}$ & 0.531 & $\begin{array}{l}573 \\
325 \\
179 \\
573\end{array}$ & $\begin{array}{l}2.64 \\
2.47 \\
2.48 \\
2.64\end{array}$ & $\begin{array}{l}0.91 \\
0.92 \\
0.92 \\
0.91\end{array}$ & $0.011^{*}$ \\
\hline $\begin{array}{l}\text { Father's } \\
\text { occupation }\end{array}$ & $\begin{array}{l}3 \\
4 \\
5\end{array}$ & $\begin{array}{l}121 \\
665 \\
367 \\
89 \\
23\end{array}$ & $\begin{array}{l}3.02 \\
2.98 \\
2.99 \\
3.19 \\
3.14\end{array}$ & $\begin{array}{l}0.69 \\
0.67 \\
0.66 \\
0.72 \\
0.71\end{array}$ & 0.085 & $\begin{array}{l}117 \\
660 \\
363 \\
89 \\
23\end{array}$ & $\begin{array}{l}2.83 \\
2.70 \\
2.65 \\
2.83 \\
2.69\end{array}$ & $\begin{array}{l}0.78 \\
0.78 \\
0.80 \\
0.94 \\
0.95\end{array}$ & 0.165 & $\begin{array}{l}104 \\
593 \\
317 \\
76 \\
22\end{array}$ & $\begin{array}{l}2.51 \\
2.60 \\
2.51 \\
2.58 \\
2.59\end{array}$ & $\begin{array}{l}0.87 \\
0.93 \\
0.96 \\
0.99 \\
0.98\end{array}$ & 0.668 \\
\hline $\begin{array}{l}\text { Mother's } \\
\text { occupation }\end{array}$ & $\begin{array}{l}3 \\
4 \\
5\end{array}$ & $\begin{array}{l}181 \\
169 \\
351 \\
475 \\
100\end{array}$ & $\begin{array}{l}2.75 \\
2.66 \\
2.72 \\
2.68 \\
2.76\end{array}$ & $\begin{array}{l}0.83 \\
0.87 \\
0.76 \\
0.79 \\
0.87\end{array}$ & 0.705 & $\begin{array}{l}183 \\
170 \\
355 \\
481 \\
101\end{array}$ & $\begin{array}{l}3.16 \\
3.08 \\
2.99 \\
2.93 \\
2.97\end{array}$ & $\begin{array}{l}0.69 \\
0.66 \\
0.69 \\
0.65 \\
0.73\end{array}$ & $0.001^{*}$ & $\begin{array}{l}166 \\
154 \\
321 \\
439 \\
93\end{array}$ & $\begin{array}{l}2.88 \\
2.83 \\
2.89 \\
2.79 \\
2.78\end{array}$ & $\begin{array}{l}0.85 \\
0.89 \\
0.79 \\
0.79 \\
0.84\end{array}$ & 0.449 \\
\hline $\begin{array}{l}\text { Father's } \\
\text { education } \\
\text { level }\end{array}$ & $\begin{array}{l}\text { Primary } \\
\text { Secondary } \\
\text { Bachelor } \\
\text { Master/Ph } \\
\text { D }\end{array}$ & $\begin{array}{l}116 \\
611 \\
460 \\
125\end{array}$ & $\begin{array}{l}3.19 \\
3.02 \\
2.94 \\
2.97\end{array}$ & $\begin{array}{l}0.75 \\
0.69 \\
0.66 \\
0.66\end{array}$ & $0.04^{*}$ & $\begin{array}{l}116 \\
606 \\
452 \\
123\end{array}$ & $\begin{array}{l}2.84 \\
2.68 \\
2.69 \\
2.73\end{array}$ & $\begin{array}{l}0.82 \\
0.80 \\
0.79 \\
0.79\end{array}$ & 0.224 & $\begin{array}{l}105 \\
532 \\
407 \\
109\end{array}$ & $\begin{array}{l}2.89 \\
2.50 \\
2.57 \\
2.53\end{array}$ & $\begin{array}{l}1.11 \\
0.90 \\
0.90 \\
0.97\end{array}$ & $0.011^{*}$ \\
\hline $\begin{array}{l}\text { Mother's } \\
\text { education } \\
\text { level }\end{array}$ & $\begin{array}{l}\text { Primary } \\
\text { Secondary } \\
\text { Bachelor } \\
\text { Master/Ph } \\
\text { D }\end{array}$ & $\begin{array}{l}89 \\
615 \\
494 \\
107\end{array}$ & $\begin{array}{l}3.27 \\
3.03 \\
2.92 \\
2.96\end{array}$ & $\begin{array}{l}0.74 \\
0.68 \\
0.66 \\
0.68\end{array}$ & $<0.01^{*}$ & $\begin{array}{l}88 \\
609 \\
491 \\
103\end{array}$ & $\begin{array}{l}2.82 \\
2.70 \\
2.70 \\
2.63\end{array}$ & $\begin{array}{l}0.89 \\
0.81 \\
0.78 \\
0.80\end{array}$ & 0.397 & $\begin{array}{l}82 \\
562 \\
448 \\
82\end{array}$ & $\begin{array}{l}3.05 \\
2.84 \\
2.82 \\
3.05\end{array}$ & $\begin{array}{l}1.03 \\
0.52 \\
0.75 \\
1.03\end{array}$ & 0.098 \\
\hline
\end{tabular}

Table 4 presents the analysis on the relationship between students' characteristics and their accounts on support provision. First, the variable Amean is significantly larger for male 
students compared to females, students at their $3^{\text {rd }}$ or $4^{\text {th }}$ year of studies compared to those who have extended the official period of study, first generation students, students with low paternal and maternal educational level and students with unemployed mother and students attending UniC compared to those at the other two institutions under study. The aforementioned categories of students consider the support provided to be greater compared to students without these characteristics. Taking into account that these students have no privileged social, economic and academic background, their satisfaction from the current provision might reveal that the new forms of inequalities triggered make some other groups of students more vulnerable and in need of support in higher education.

Second, the variable Bmean is significantly larger for males, first generation students, students at their $3^{\text {rd }}$ or $4^{\text {th }}$ year of studies, students with low paternal education level or unemployed mother and students attending UniC.

Third, as regards variable $\mathrm{C}$, it is significantly larger for males, students at their $3^{\text {rd }}$ or $4^{\text {th }}$ year of studies, students with low paternal and maternal education level, students whose cost of studies is less than 300 euros per month and students attending UniC.

\section{Discussion - Conclusions}

Drawing on a set of quantitative data collected for our research project, this article presents how undergraduate students account on the support provision in Greek higher education. Our findings show that students, in their majority, express rather reserved views on the readiness and effectiveness of institutions to implement specific practices of support regarding teaching staff and fellow students, their satisfaction about the support measures they met by their institution in order to have a better social and academic engagement and their perspectives about the support measures taken in order to combat inequalities. This finding is of importance as relevant studies show the significance of support services regarding information, advice and guidance (Thomas \& Jones, 2007) and meaningful interaction between staff and students (Thomas, 2012) on students' progression.

Second, when students find university less supportive for some aspects, the same applies for all support aspects. This finding raises concerns regarding the effectiveness of student support services which have been established at Greek HE institutions after Law 4009/2011 to enhance students' retention and completion of studies (EC, 2019). However, relevant problems exist, inequalities persist (Crozier et al., 2019; Reay, 2017) and, although in the Greek context, the "social dimension of higher education" in relation to access to higher education, progression and completion rates is considered (EC, 2018), student support provision in higher education is underresearched (Stamelos, 2020).

Third, some aspects related to students' background and attendance relate to how they perceive student support. In particular, aspects, such as students' economic background, parental educational level, being a first generation student, which have been traditionally seen as key to inequalities in higher education, do not appear to impact on the respondents' views on how supportive Greek higher education institutions are. The implementation of widening participation initiatives and key support services, the provision of grants as well as the absence of fees for undergraduate studies might have had a positive impact on that. In contrast to the aforementioned characteristics, some others, such as gender, non-completion of studies on time and institution of attendance matter.

In particular, male students find university more supportive for the three categories of support under study. While females' entrance, attendance and completion rates are high (ADIP, 2019), this finding shows that gendered types of inequalities exist. This finding also seems of importance nowadays as most Greek higher education institutions establish committees on gender 
inequalities. As regards the year of study, students who are attending their $3^{\text {rd }}$ or $4^{\text {th }}$ year of studies find university more supportive compared to those who run late. In the Greek context, late or noncompletion is reported as a problem (EC, 2019). However, because of the fact that relevant policies have emphasized, up to now, these students' de-registration from the institutions' records as a policy measure to reduce their numbers, we suggest further investigation of these students' need for support. In addition, students who do not complete their studies on time might need to be seen in relation to mature students. Studies on such topics have not been conducted for the Greek case, however, studies at an international level show mature students' need for support (McVitty \& Morris, 2012).

Finally, the most striking finding of the present study is that the institution of attendance is indicated as a factor differentiating students' accounts on the support measures provided revealing the key role of institution and institutional differences in students' academic trajectories for the Greek case. This finding informed our decision to further investigate aspects of institutional culture of the three institutions under study which is the scope of another article under publication.

We need to note that the statistically significant differences appear for the same characteristics of students as regards the three aspects of support provision, that is to say gender, year of study and institution of attendance. It is also worthy to note that aspects related to economic background and parental educational level are not raised as significant. Therefore, new insights are provided for understanding aspects of current inequalities in higher education.

The present study indicates the need to further examine the effectiveness of the existing student support services in the Greek higher education context, first in terms of what is provided and, second, how well it is provided. Moreover, the study shows that every attempt to implement HE policies for student support should consider the existing differences among higher education institutions.

\section{Acknowledgements}

The project "Educational trajectories in Greek higher education: Diversity, Inequalities and Inclusion" has been co-financed by the Operational Program "Human Resources Development, Education and Lifelong Learning" and is co-financed by the European Union (European Social Fund) and Greek national funds (2014-2020).

This research did not receive any specific grant from funding agencies in the public commercial, or not-for-profit sectors.

The authors declare no competing interests.

\section{References}

ADIP/Quality assurance and certification in higher education, ADIP (2019). Higher Education Quality Report. Athens (in Greek).

Archer, L. (2007). Diversity, equality and higher education: a critical reflection on the ab/uses of equity discourse within widening participation. Teaching in Higher Education, 12(5-6), 635-653.

Archer, L., \& Hutchings, M. (2000). 'Bettering yourself'? Discourses of risk, cost and benefit in ethnically diverse, young working-class non-participants' constructions of higher education. British Journal of Sociology of Education, 21(4), 555-574. 
Archer, L., Hutchings, M., \& Ross, A. (2003). Higher education and social class: Issues of exclusion and inclusion. London and New York: Routledge Falmer.

Askouni, N. (2006). The education of the (Muslim) minority in Thrace: From the margin to the prospect of inclusion. Athens: Alexandreia (in Greek).

Barberis, E., \& Loncle, P. (2015). Governance and disadvantage: Institutional opportunity structures at local level. In M. Parreira do Amaral, R. Dale and P. Loncle (Eds.), Shaping the futures of young Europeans: Education governance in eight European countries (pp. 151-69). Bristol: Symposium Books.

Buchmann, C., \& DiPrete, T. A. (2006). The growing female advantage in college completion: the role of family background and academic achievement. American Sociological Review, 7(14), 515-541.

Burke, P. J., Crozier, G., \& Misiaszek, L. I. (2016). Changing pedagogical spaces in higher education: Diversity, inequalities and misrecognition. Routledge.

Croll, P., \& Attwood, G. (2013). Participation in higher education: Aspirations, attainment and social background. British Journal of Educational Studies, 61(2), 187-202.

Crozier, G., \& Reay, D. (2008). The socio-cultural and learning experiences of working class Students in HE: ESRC full research report. Swindon: Economic and Social Research Council. Retrieved 14 June 2020 from http://www.esrc.ac.uk/my-esrc/grants/RES-139-25o208/outputs/Read/652b5c30-d2c5-4051- 9298-e593b2a3d519.

Crozier, G., Reay, D., \& Clayton, J. (2008). Different strokes for different folks: diverse students in diverse institutions. Research Papers in Education, 23(2), 167-177.

Crozier, G., Reay, D., \& Clayton, J. (2019). Working the Borderlands: working-class students constructing hybrid identities and asserting their place in higher education. British Journal of Sociology of Education, 1-17.

European Commission/EACEA/Eurydice (2018). National student fee and support systems in European Higher Education - 2018/19. Eurydice - Facts and Figures. Luxembourg: Publications Office of the European Union. Retrieved 24 July 2020 from https://eacea.ec.europa.eu/nationalpolicies/eurydice/content/national-student-fee-and-support-systems-european-highereducation-201819 en.

European Commission/EACEA/Eurydice (2019). Structural indicators for monitoring education and training systems in Europe - 2019: Overview of major reforms since 2015. Retrieved 24 July 2020 from https://eacea.ec.europa.eu/nationalpolicies/eurydice/sites/eurydice/files/structural indicat ors 2019.pdf.

Foster, E., Lawther, S., Keenan, C., Bates, N., Colley, B., \& Lefever, R. (2011). The HERE Project. Higher Education: Retention \& Engagement. Nottingham: Nottingham Trent University.

Long, B. T. (2008). What is known about the impact of financial aid? Implications for policy. NCPR Working Paper. National Center for Postsecondary Research. Retrieved 24 March 2020 from http://ccrc.tc.columbia.edu/publications/impact-of-financial-aid.html.

McVitty, D., \& Morris, K. (2012). Never too late to learn: Mature students in higher education. London: Million+/NUS. Retrieved 25 April, 2020 from

http://www.millionplus.ac.uk/documents/reports/Never_Too Late To Learn FINAL R EPORT.pdf.

Purcell, K., Elias, P., Atfield, G., Behle, H., Ellison, R., Hughes, C., \& Tzanakou, C. (2009). Plans, aspirations and realities: taking stock of higher education and career choices one year on. Manchester: HECSU. Retrieved 30 April, 2020 from https://warwick.ac.uk/fac/soc/ier/futuretrack/findings/futuretrack stage 2 report plans aspirations and realities.pdf.

Reay, D. (2017). Miseducation: Inequality, education and the working classes. Bristol: Policy Press. 
Reay, D., Crozier, G., \& Clayton, J. (2009). 'Strangers in paradise'? Working class students in elite university. Sociology, 43(6), 1103-1121.

Saiti, A., \& Prokopiadou, G. (2008). The demand for higher education in Greece. Journal of Further and Higher Education, 32(3), 285-296, https://doi.org/10.1080/03098770802221080

Shavit, Y., Arum, R., \& Gamoran, A. (2007). Stratification in higher education: A comparative study. Stanford: Stanford University Press.

Sianou-Kyrgiou, E. (2010). Stratification in higher education, choice and social inequalities in Greece. Higher Education Quarterly, 64, 22-40.

Sianou-Kyrgiou, E., \& Tsiplakides, I. (2011). Similar performance, but different choices: Social class and higher education choice in Greece. Studies in Higher Education, 36(1), 89-102.

Stamelos, G. (2020). Transforming higher education. The democratization of the university and its limits. Patra: HepNet (in Greek).

Thomas, L. (2002). Student retention in higher education: The role of institutional habitus. Journal of Education Policy, 17(4), 423-442.

Thomas, L. (2012). What works? Facilitating an effective transition into higher education. Widening Participation and Lifelong Learning, 14, 4-24.

Thomas, L., \& Jones, R. (2007). Embedding employability in the context of widening participation. York: Higher Education Academy. Retrieved 6 June, 2020 from http://www.heacademy.ac.uk/assets/documents/employability/ESECT WideningParticipati on.pdf.

Trowler, V. (2010). Student engagement literature review. York: Higher Education Academy.

Troxel, W. (2010). Student persistence and success in United States higher education: A synthesis of the literature. York: Higher Education Academy.

Wilcox, P., Winn, S., \& Fyvie-Gauld, M. (2005). It was nothing to do with the university, it was just the people: the role of social support in the first year experience of higher education. Studies in Higher Education, 30(6), 707-722.

Zmas, A. (2015). Financial crisis and higher education policies in Greece: Between intra- and supranational pressures. Higher Education, 69, 495-508. https://doi.org/10.1007/s10734-014-9787-0 
O. Tzafea et al. - Support Provision in Greek Higher Education: Examining Students' Accounts

C O A $\mathrm{s}$ 